\title{
Rearing of the red palm weevil, Rhynchophorus ferrugineus (Olivier) on different natural diets.
}

\author{
El-Zoghby, I.R.M. ${ }^{1}$ and Naglaa F. Abdel-Hameid ${ }^{2}$ \\ ${ }^{1}$ Plant Prot. Dept., Faculty of Agric. and Natural Resources, Aswan Univ., Aswan, Egypt \\ ${ }^{2}$ Plant Protection Dept., Faculty of Agriculture, Benha Univ., Egypt. \\ Corresponding author: ielzoghby77@agr.aswu.edu.eg
}

\begin{abstract}
Five different diets (Small pieces of sugarcane stems, Sugarcane stem pieces + Sugarcane residues, Sugarcane stem pieces + Date palm trunk pieces, Sugarcane stem pieces + Grinded frond of date palm and Sugarcane stem pieces + Food residues of RPW) were tested for rearing the red palm weevil Rhynchophorus ferrugineus and to investigate the effect of diets on some biological aspects under laboratory conditions. Larval durations of different instars were affected by different diets.

The larvae fed on (Sugarcane stem pieces + Grinded frond of date palm), slowly developed to exhibit the longest duration of 103.78 days. Meanwhile, the larvae fed on the other diets showed a gradual shortage in larval periods to give means of 89.47 and 74.63 days when fed on Small pieces of sugarcane stems and Sugarcane stem pieces + Food residues of RPW, successively.

Feeding on different diets had great effect on the means of the pupal period, which were obtained between the tested diets. Longevity of males and females emerged from larvae fed on the different tested diets varied.

The sex-ratio of emerged adults was the highest (more females), when larvae were fed on sugarcane stem pieces + food residues of RPW. Mean number of eggs deposited by emerged females from larvae fed on different diets was highest in case of (Sugarcane stem pieces + Food residues of RPW). The mean of incubation period of eggs laid from adult fed on three tested diets ranged from 3.78 to 4.54 (Sugarcane stem pieces + Food residues of RPW and Sugarcane stem pieces + Grinded frond of date palm, respectively. Hatchability percentage proved to be affected by different diets. The superior diet were sugarcane stem pieces + Food residues of RPW, because of biology completed and the diet kept moisture and remained fresh all the time.
\end{abstract}

Key words: Biological aspects, feeding diets, Rhynchophorus ferrugineus

\section{Introduction}

The date palm, Phoenix dactylifera L. is the most common and widely cultivated in the arid regions of the Middle East and North Africa. In many areas, the date palm fruit has provided the stable carbohydrate food of local people since long ago (Jones, 1995).

Red palm weevil (RPW) Rhynchorphorus ferrugineus (Olivier) (Coleoptera: Curculionidae) was first described in India as a serious pest of coconut palm (Lefroy, 1906) and later on it was reported on date palm (Lal, 1917; Buxton, 1918). During the last decade of the $20^{\text {th }}$ century, a new most serious insect pest, namely the red palm weevil, $R$. ferrugineus was firstly recorded in date palm plantations in Egypt (Saleh, 1992; and Saleh and Gouhar, 1993).

It is likely that the origin of this pest was South East of Asia, mainly in Pakistan, India, Burma, Bangladesh and Indonesia, as it has been reported by International Institute of Entomology in London (Liver, 1969) and spread later in many other countries where date palms are grown such as Iran and Arabian countries; Iraq, Saudi Arabia, Emirates and recently in Egypt. This weevil has been reported on 19 palm species belonging to 15 different genera (Barranco et al., 2000; EPPO, 2008 and Dembilio et al., 2009).
The (RPW), is an economically important invasive tissue borer that has a broad host range restricted to palm trees, mostly young trees less than 20 years old (Wattanapongsiri 1966); Kaakeh, 2005 and Faleiro, 2006). Red palm weevil is a concealed tissue borer and spends all of its life stages inside the palm tree. According to Abraham (1998), damage symptoms can be categorized by one or more of the following: presence of the tunnels on the trunk and base of leaf petioles made by the feeding grubs, oozing out of thick yellow to brown fluid from the tree, appearance of chewed up plant tissues in and around openings in the trunk, presence of a fermented odor from the fluid inside infested tunnels in the trunk, presence of adults and cocoons in the leaf axils, fallen empty cocoons on the ground around the palm, breaking of the trunk or toppling of the crown when the palm is severely infested.

Duration of all life parameters varies significantly (Kaakeh, 2005). The entire life-cycle takes about 45 to 298 days depending upon weather conditions. Seasonal activity of RPW varied between months and within the same month, (El-Garhy,1996). Several overlapping generations may be seen inside an infested palm (Faleiro, 2006). Different natural diets were developed and were tested for mass rearing of RPW (Kaakeh, 2005).

Control of RPW is difficult due to the concealed nature of the life-cycle of the pest. Integrated Pest 
Management (IPM) strategy has been applied successfully to deal with RPW problem (Faleiro, 2006 and Justin et al., 2008). Many studies conducted on RPW required large numbers of weevils of various stages, hence rearing is needed to solve the problem. The main objective of this study was to evaluate the effect of red palm weevil rearing using different diets on some biological aspects of this pest under laboratory condition in Egypt.

\section{Materials and Methods}

\section{Insects}

Various stages of RPW used in this study were originally obtained from infested palm trees in Qassasin district (Ismailia Governorate) during 2017. Each developmental stage was placed individually in rectangular plastic boxes with press-on tight-fitting lids $(30 \times 20 \times 15 \mathrm{~cm}$.) (Fig. 1). Portable wood saw was used to facilitate collecting weevils from heavily infested palm trees.

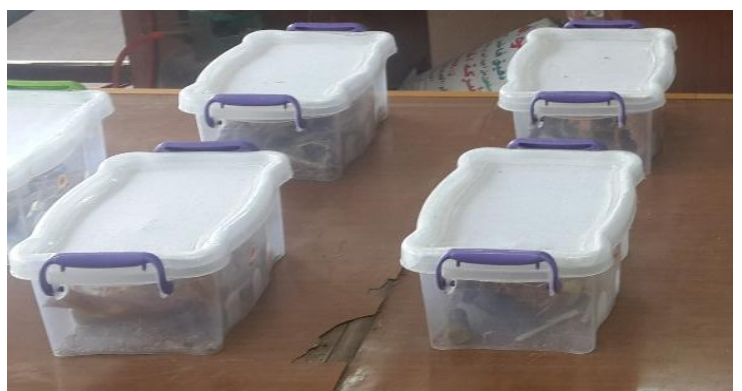

Figure 1. Rectangular plastic containers containing culture of RPW

\section{Rearing Room}

The insects were cultured in a rearing room of the Insect Research Laboratory at the Plant Protection Department, Fac. of Agri. at Moshtohor, Benha University. The room was maintained at $\left(28 \pm 1^{\circ} \mathrm{C}\right.$, $75 \pm 5 \%$ R.H.). The photoperiod was approximately $12: 12$. The room contained three large working benches, electrical outlets and side boards. The room was also used as a media room for handling and preparing materials of natural diets.

Larvae and adults of $R$. ferrugineus were provided with sugarcane stem pieces for feeding. Adults were sexed after emergence and kept separately in small jars prior to the beginning of the observations (Fig. 2). Sexing of adults was done according to the presence of a series of black hairs on the dorsal, frontal part of snouts of males and their absence in the females.

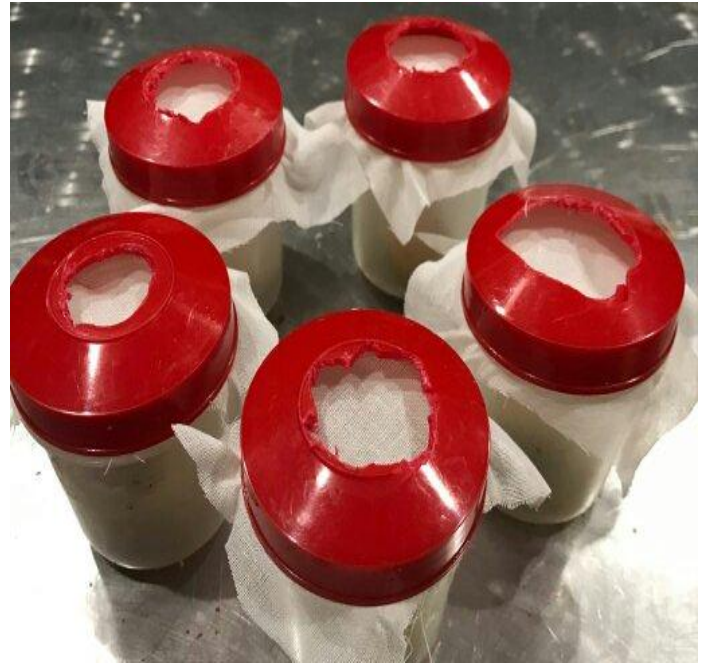

Figure 2. Jars containers containing unsexed groups of adults

\section{Preparation of Diets}

Figure 3, shows the main ingredients of natural diets used in this study. The methodology of rearing $R$. ferrugineus on sugarcane stem pieces and natural diets were previously reported by Kaakeh et al. (2001). Natural diets were prepared for mass rearing of $R$. ferrugineus because of the availability of sugarcane in Egypt in culturing this insect. Diets were also developed to avoid the use of expensive artificial diets for culture of weevils. All plastic boxes were stored at room temperature until required. Larvae were placed on diets after total coolness. Five natural diets as described in (Fig. 3). No other ingredients were added or mixed with these diets:

Diet 1 , is mainly sugarcane stems, this diet proved hardly succeeded because of sugarcane stem damage by drought. The phases were separated because the ages were not completed and put on new sugarcane stems. This diet was found expensive and not easily handled.

Diet 2, contains sugarcane stem pieces + sugarcane residues. This diet was created to avoid sugarcane stem drought by adding sugarcane residues, but drought was less than diet 1. Decay happened, so biology was not completed, and phases were separated. Diet 3, consists of sugarcane stem pieces + date palm trunk pieces as a natural diet. This diet was found expensive and exhausted and biology was not completed. Diet 4, composed of sugarcane stem pieces + grinded frond of date palm. This diet kept the moisture and decay didn't occur, biology was completed but after longer duration.

The superior diet considered was that of sugarcane stem pieces + food residues of RPW (Diet 5 ), because of biology easily completed and the diet kept moisture and remained fresh all the time. 


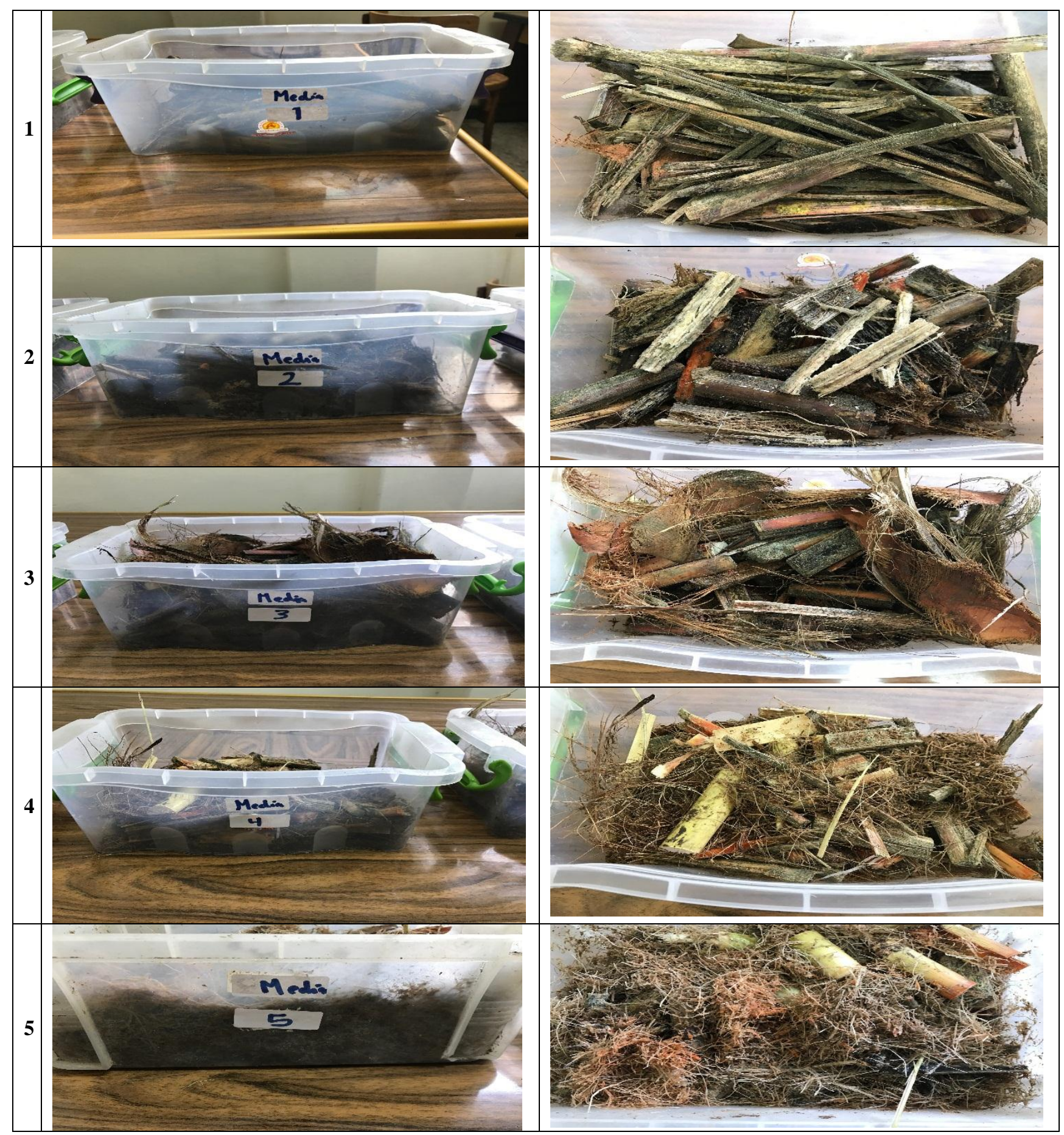

Figure 3. Natural diets in plastic containers for feeding of larvae of various sizes of RPW;

1. Small pieces of sugarcane stems

2. Sugarcane stem pieces + Sugarcane residues

3. Sugarcane stem pieces + Date palm trunk pieces

4. Sugarcane stem pieces + Grinded frond of date palm

5. Sugarcane stem pieces + Food residues of RPW 
All larvae were fed by either of the fifth natural diets until those became fully matured, then transferred to sugarcane stems for making cocoons. Additional studies are required to search for alternative food sources to develop diets that $R$. ferrugineus can fully develop on it without transferring last larval instar to sugarcane stems for construction of cocoons.

\section{Effect of different diets on some biological aspects of $R$. ferrugineus}

\section{Duration of egg stage}

Cocoons of red palm weevil (RPW) were put in containers as described before, these cocoons were kept till adults' emergence. The newly emerged adults (20 pairs of newly emerged male and female weevils) were collected and reared in the containers with different diets.

The insects were left for one week to copulate, the eggs laid by females were removed daily by peeling the fibrous tissues, picking up eggs using a soft hair brush no. zero (camel's brush). Eggs were transferred with the camel hair brush and placed on wet filter papers to avoid drying inside the petri dishes for further studies, where eggs were monitored until hatching.

Many newly laid eggs almost of the same age (0.0-24 hours old) were available to initiate the insect first generation .The Petri dishes were put in an incubator in the laboratory $\left(28 \pm 1^{\circ} \mathrm{C}, 75 \pm 5 \%\right.$ R.H. $)$ and inspected daily to observe eggs hatching.

The viability of the eggs was determined by counting the number of hatched eggs per 100 eggs. After 3 to 4 days, larvae from hatched eggs were removed to separate small cups $(4 \times 4 \mathrm{~cm}$.) and provided with different components of different diets which were prepared for feeding (Fig. 4).

Sugarcane stems were cut off from the middle and divided into pieces. Food was replaced every 3 days and the old pieces were confined in separate containers for seven days before examination for weevil eggs and/or larvae. The stages of weevils were examined daily for mortality.
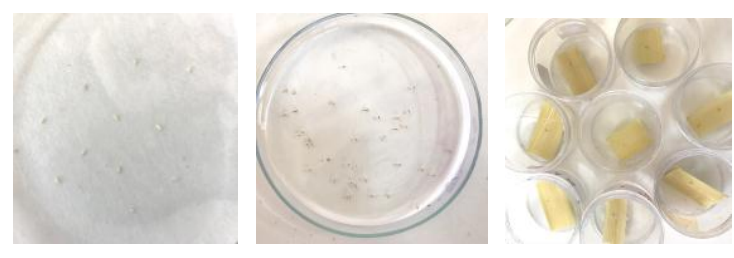

Figure 4. Monitoring Eggs of RPW until hatching

\section{Longevity (larvae and adult development times)}

Freshly hatched larvae of $R$. ferrugineus $(\mathrm{n}=20)$ were transferred with a camel's hair brush to different diets. Last larval instars, fed on various diets, were transferred to sugarcane stem pieces to make cocoons. The size of sugarcane stem pieces was dependent on the size of larvae at different developmental stages. Last larval instars made cocoons from the fibers inside the sugarcane stems. The following developmental parameters were recorded: larval period, pupal period and adult male $\&$ female longevities.

Containers were staked side by side or on the top of each other on working benches. Few pores were made on all lids of boxes and jars for ventilation. Paired males and females were kept together, then deposited eggs were transferred from the grated sugarcane stems, using a camel hair brush, and placed on wet filter papers inside the Petri dishes.

\section{Number and duration of larval instars}

To study the number of larval instars as well as the duration of each instar, 20 newly hatched larvae were used by introducing each larva in a plastic cup (4 x $4 \mathrm{~cm}$.), and tightly covered with a perforated cover. Larvae were inspected daily by using lens during the first three instars to record the date of moulting by observing exuvia, whereas during other instars larvae were largen in size and their exuviae were easily distinguished by naked eyes.

\section{Pupae}

When larva become full-grown, it starts to spin a cocoon from fibers mixed with an adhesive saliva. Inside the formed cocoon, the larva passes through the pupal stage. The stem pieces of sugarcane were split open and cocoons were collected, (Fig. 5). Cocoons of $R$. ferrugineus placed in a plastic container, mist of water was supplied as needed, and closed with lids. After collecting the cocoons, they were checked daily for adult emergence.

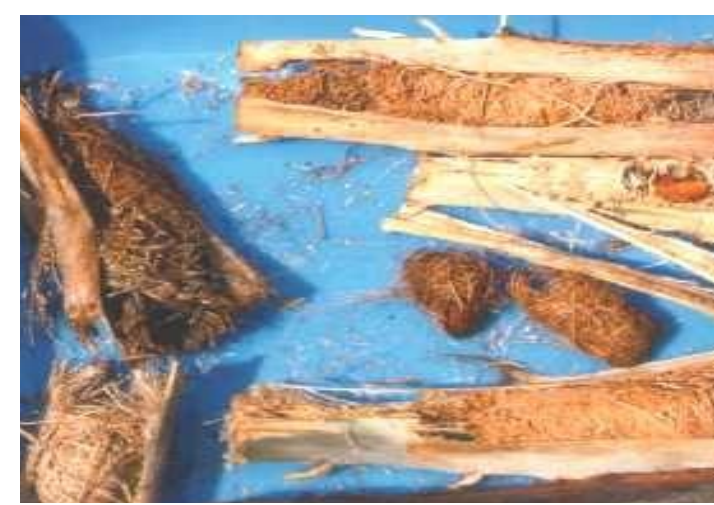

Figure 5. Collection of pupae of $R$. ferrugineus from pieces of sugarcane stems

\section{Adults}

Adults were sexed after emergence from cocoons and kept separately in small 1-liter glass jars (one pair/ box), (Fig. 6) prior to the beginning of the observations of mating and egg- laying. After adult's emergence from cocoons. These jars were provided with rasped shreds of sugarcane stem pieces and inspected daily to record the date of laying the first egg as well as the daily number of eggs deposited till 
the end of female life to determine female fecundity, the $\%$ hatching rate and male \& female longevites were determined. When the first newly emerged female began to lay eggs, the second generation was initiated on this date, and so on.

Adults collected from the field were kept (as group of at least 10 males and females but not sexed) in or kept as pairs of males and females in jars. All adults were provided with at least 5 absorbent cotton wicks saturated with a 10\% honey solution for feeding and egg laying. Boxes and jars were staked side by side (or on the top of each other) on working benches. Pores were made on all lids of boxes and jars for ventilation.

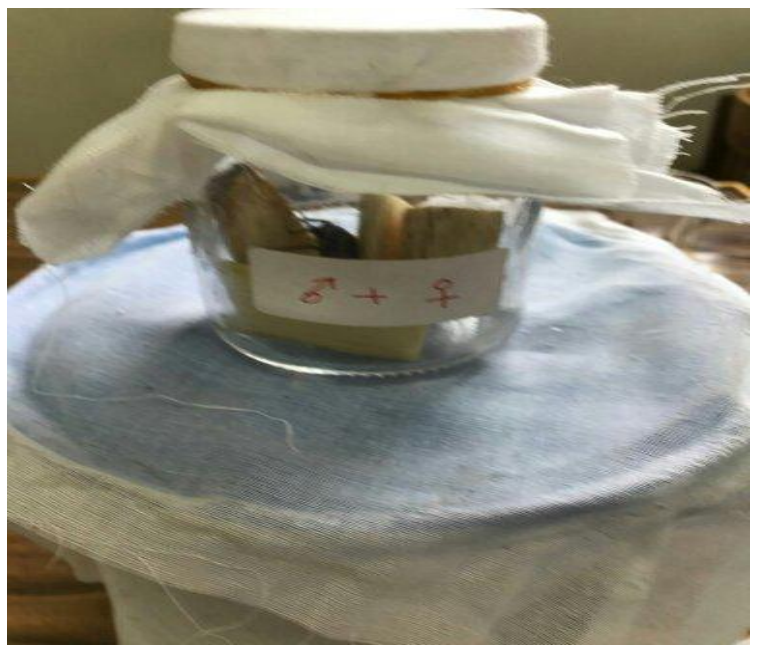

Figure 6. Glass jar holding adults for mating and oviposition (pairs of sexed males and females)

\section{Statistical analysis:}

The statistical analysis was carried out using ANOVA under significance level of 0.05 for the whole results using SPSS (ver. 22). Data were treated as complete randomization design according to Steel et al. (1997). Multiple comparisons were carried out applying LSD.

\section{Results and Discussion}

\section{Incubation period of egg}

Data in Table (2) showed that feeding on different diets had affected the complete life- cycle of RPW (Fig. 7). The eggs are laid individually by female weevils in separate holes excavated by its snout (Fig. 8). Eggs are creamy white, shiny and oblong. Prior to hatching, larval mouthparts can be observed through the egg shell. Egg hatching occurs after 3.78 to 4.54 days from oviposition depending on different diets, (Sugarcane stem pieces + Food residues of RPW \& Sugarcane stem pieces + Grinded frond of date palm, respectively; Table, 2). The obtained results clearly indicate that statistically insignificant differences were detected between means of the three tested diets.

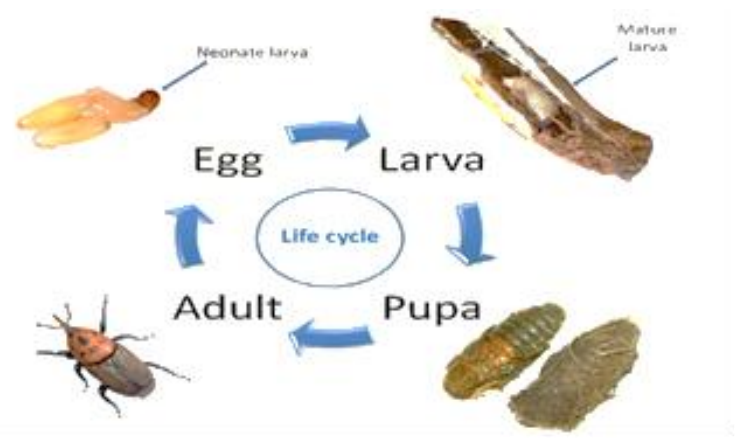

Figure 7: Life cycle of $R$. ferrugineus

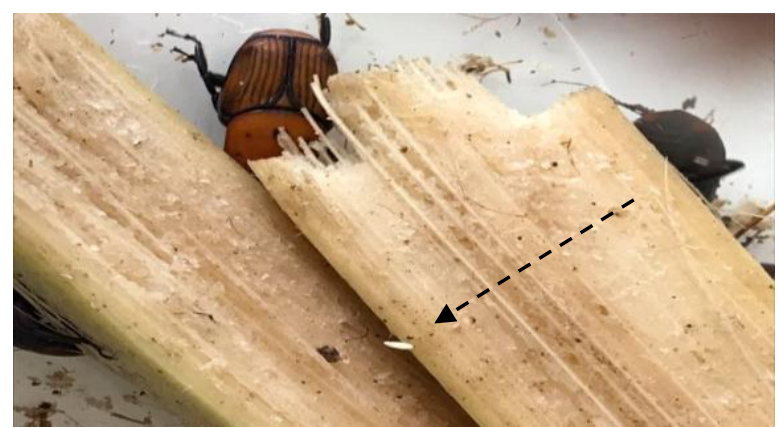

Figure 8: Holes in the sugar cane by RPW larvae

\section{Effect of different diets on the duration of larval instars}

Larvae are apodous creamy white in color with a brownish head and body comprised of 13 segments. The head capsule is brown russet-red to brilliant brown-black with strongly chitinized mouthparts (Fig. 9).

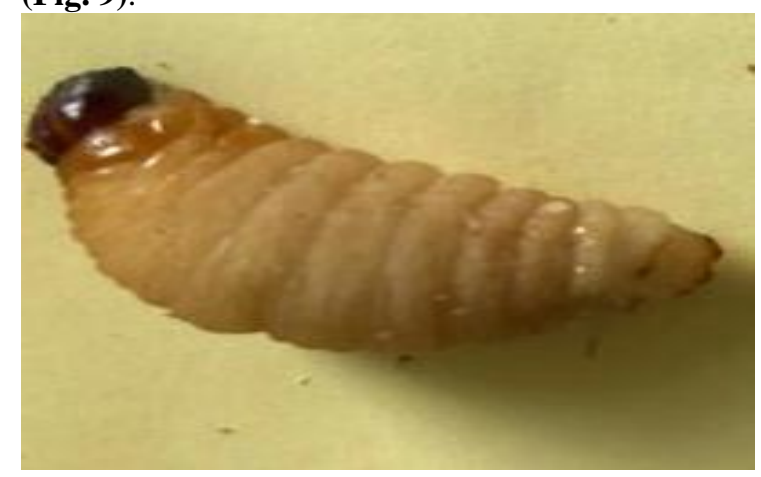

Figure 9: Larva of $R$. ferrugineus

The average of larvae at various stages, survival, percentage of larvae that went into cocoon, and percentage of emergence of adults varied greatly between the diets tested. Data revealed that the larval duration affected according to different diets, except for diets 2\&3 (Sugarcane stem pieces + Sugarcane residues and Sugarcane stem pieces + Date palm trunk pieces).

As shown in Table (1), the duration of early three instars $\left(1^{\text {st }}, 2^{\text {nd }}\right.$ and $3^{\text {rd }}$ ranged between 1.27 days (Sugarcane pieces + Food residues of RPW) to 2.17 
days (Sugarcane stem pieces + Grinded frond of date palm), 2.02 days (Sugarcane stem pieces + Food residues of RPW) to 2.99 days (Sugarcane pieces + Sugarcane residues). This period lasted 1.65 days (Sugarcane stem pieces + Food residues of RPW) to 3.11 days (Sugarcane stem pieces + Grinded frond of date palm) for the $1^{\text {st }}, 2^{\text {nd }}$ and $3^{\text {rd }}$ instars, respectively.

The duration of the $4^{\text {th }}, 5^{\text {th }}, 6^{\text {th }}$ and $7^{\text {th }}$ larval instars slightly prolonged to record means of 2.63 days (Sugarcane stem pieces + Food residues of RPW) to 3.93 days (Sugarcane stem pieces + Grinded frond of date palm), 2.95 days (Sugarcane stem pieces + Food residues of RPW) to 4.02 days (Sugarcane stem pieces + Grinded frond of date palm), 3.05 days (Sugarcane stem pieces + Date palm trunk pieces) to 5.05 days (Sugarcane stem pieces + Date palm trunk pieces) and 4.06 days (Sugarcane stem pieces + Food residues of RPW) to 6.92 days (Small pieces of sugarcane stems), for the mentioned 4 instars, respectively.

The prolonged duration of the $8^{\text {th }}$ and $9^{\text {th }}$ larval instars ranged between 5.71 days (Sugarcane stem pieces + Food residues of RPW) to 8.11 days (Sugarcane stem pieces + Grinded frond of date palm) and 10.12 days (Sugarcane stem pieces + Food residues of RPW) to 14.19 days (Sugarcane stem pieces + Grinded frond of date palm). The duration of the $10^{\text {th }}, 11^{\text {th }}$ instars ranged between 12.97 days (Sugarcane stem pieces + Food residues of RPW) to 17.91 days (Sugarcane stem pieces + Grinded frond of date palm) , 13.69 days (Sugarcane stem pieces + Food residues of RPW) to 17.53 days (Sugarcane stem pieces + Grinded frond of date palm), respectively. Larvae fed on sugarcane stem pieces + Food residues of RPW, Small pieces of sugarcane stems and sugarcane stem pieces + grinded frond of date palm only gave the $12^{\text {th }}$ instar, the duration was 14.43, 16.1 and 18.73 days, respectively, Table (1).

The number of larval instars varied depending on the diet or host plant. Larvae were fully developed (12 times) on natural diets sugarcane stem pieces + food residues of RPW \& sugarcane stem pieces + grinded frond of date palm and small pieces of sugarcane stems . While, in case of sugarcane stem pieces + Date palm trunk pieces, the instars didn't reach 8 instars.

When larvae were reared on the diet composed from sugarcane stem pieces + sugarcane residues, the larva couldn't reach the $4^{\text {th }}$ instar Table (1), this may be attributed to the unavailability of fibers (palm or sugarcane) or there were not enough quantities of high fiber substrates in the diet.

\section{Effect of different diets on total duration of larval stage}

Data compiled in Table (2) show the duration of larval instars during the first generation of red palm weevil, $R$. ferrugineus fed on the succeeded different diets. Statistical analysis of data reveals that the larval duration was significantly affected according to different diets.

Table (2) showed that feeding on different diets had a strong effect on the duration of larvae, since the larvae fed on sugarcane stem pieces + grinded frond of date palm slowly developed to exhibit the longest duration of 103.78 days. Meanwhile, the larvae fed on the other diets showed a gradual shortage in larval periods to give means of 74.63 and 89.47 days when reared on sugarcane pieces + food residues of RPW and on small pieces of sugarcane stems, respectively.

In smile studies, Kaakeh et al. (2001) reported that red palm weevil completed its larval period in 50-80 days, Salama \& Abdul Razek (2002) stated that red palm weevil was successfully reared on diets having high sugar contents.

Newly emerged larvae seek their way into the sugarcane by boring through tissues and making tunnels in sugarcane stalks (Fig. 10), subsequently damage increases with every molt. Young larvae have the tendency to feed on soft tissues, while older larvae move towards feeding and grinding the harder tissues and to form a cocoon enwrapped in palm fibers (Fig. 11).

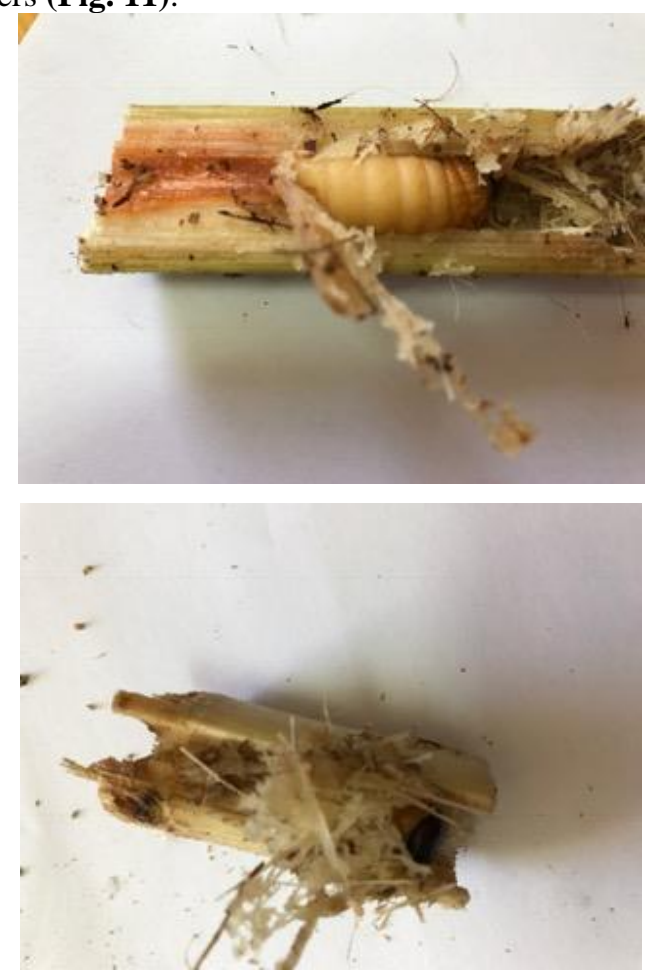

Figure 10: RPW larva tunnels 


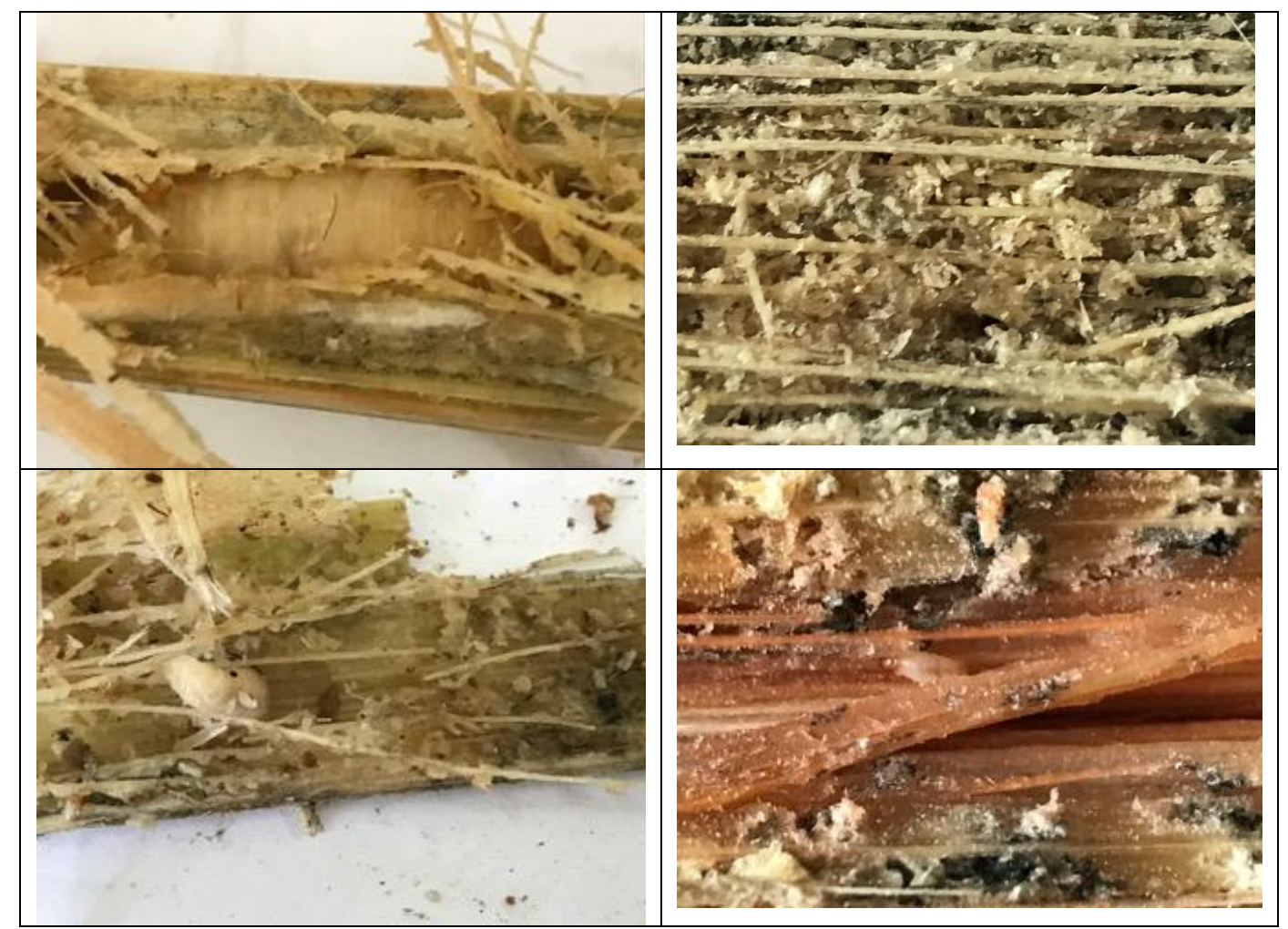

Figure 11: RPW larval feeding on natural diets

\section{Duration of pupal stage}

Concerning pupal periods of the red palm weevil , statistical analysis of results showed significant differences between the tested diets. As tabulated in Table (2), the pupal period ranged from a minimum of 21 days when rearing took place on small pieces of sugarcane stems to a maximum of 34 days by rearing on sugarcane stem pieces + grinded frond of date palm. During this period the pupa remains in their cocoons (Fig. 12) and after the pupal period is finished, the RPW pupa is transferred to the adult stage which find it way out of the cocoon to repeat its life-cycle. The pupa has an average size of $80 \times 35$ $\mathrm{mm}$. Initially pupa is creamy, and then turn brown in color (Fig. 13). The pupa is greatly furrowed with a shiny surface.

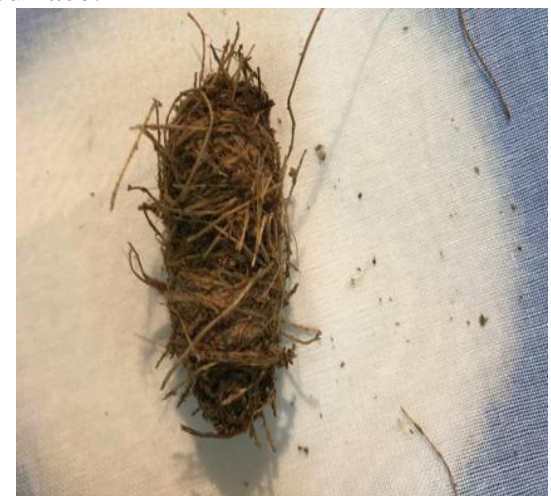

Fig. 12: Cocoon of R. ferrugineus

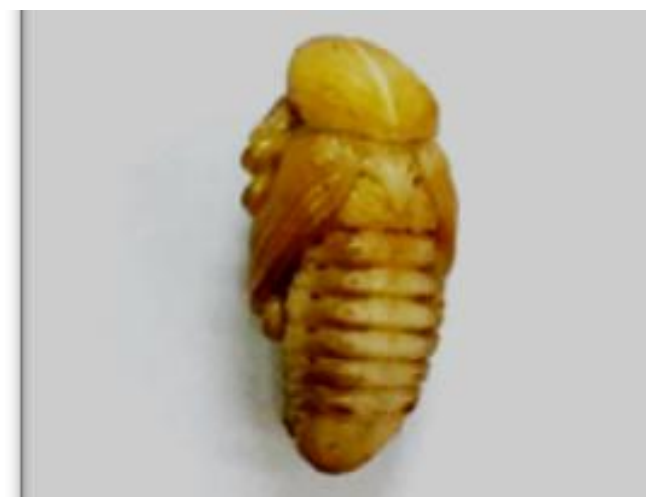

Fig. 13: Pupa of $R$. ferrugineus

Sugarcane stem was suitable for pupation because larval stages require fiber and failed to construct cocoon in any other diet (Kakeeh et al., 2001). The diet consisting of sugarcane stem pieces + food residues of RPW diet was found to be the best medium for the development of all larval stages to the pupa stage.

\section{Longevity of adults}

After the pupal development has been completed, the adult weevil emerges through the cocoon. Adults of RPW are large, rusty red in color measuring 3.43 $\pm 6.32 \mathrm{~cm}$. long and $1.19 \pm 6.32 \mathrm{~cm}$ width with a characteristic long and curved rostrum which comprises about one-third of the total body length. On the dorsal side of the thorax the weevils exhibit dark spots. In males, the anterior dorsal half of the rostrum has short brownish setae (hairs). By contrast, the female rostrum lacks any hair, and is 
comparatively narrower, more curved and longer than the male rostrum. The adult weevils have welldeveloped wings, so weevils are capable to undertake long flights (Lepesme 1947), and to cover long distances of 500-800 m (Wattanapongsiri 1966) (Fig. 14).

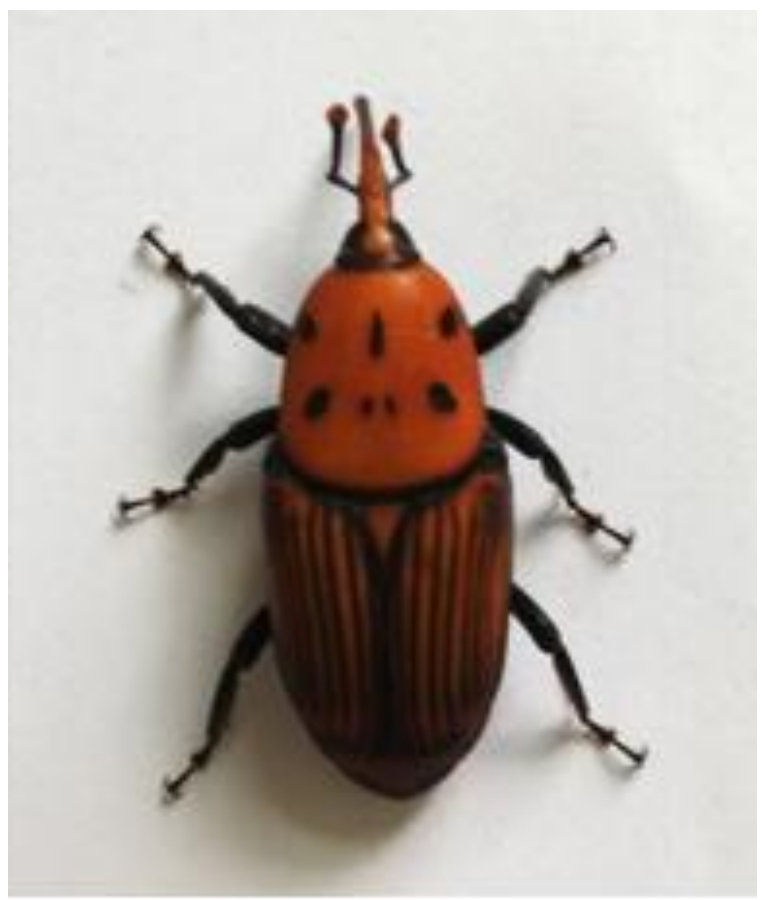

Figure 14: Adult of $R$. ferrugineus

Data presented in Table (2), show that this period had been influenced by feeding on the different tested diets. As regards adult longevity of both sexes emerged from larvae fed on the different tested diets, the present results obviously reveal that the type of diet proved to be statistically highly significant on the longevity of males and females.

The longest means of longevities (96.8 days for males and 91.24 days for females) were obtained with adults emerged from larvae fed on natural natural diet (Sugarcane stem pieces + Food residues of RPW diet).

\section{Sex ratio}

Statistical analysis of the results given in Table (2), revealed that the sex-ratio of emerged adults (as $\%$ emerged females) was not significantly impacted by variations in the type of larval food. The highest mean percentage of adult females (56.72) occurred between adults fed in the larval stage on sugarcane stem pieces + food residues of RPW diet, whereas the lowest one $(55.87 \%)$ was obtained in case of larval feeding on small pieces of sugarcane stem diet.

\section{Female fecundity of eggs}

Statistical analysis of the results given in Table (3) exhibited that the number of eggs deposited by a single mated female from larvae fed on three tested diets was high significantly varied according to the diet used. From the obtained results, the insect fecundity can be arranged descendingly as follows: 260.33, 198.76 and 191.70 eggs/female resulted from larvae fed on natural diets (sugarcane stem pieces + food residues of RPW, small pieces of sugarcane stems and sugarcane stem pieces + Grinded frond of date palm, respectively).

\section{Hatchability percentage}

Statistical analysis of the results given in Table (3) revealed that the hatchability percentage of egg was not significantly affected by variations in the type of larval food. The highest mean percentage of hatchability $(86.01 \%)$ occurred with larvae fed on (Sugarcane stem pieces + Food residues of RPW diet), whereas the lowest one $(83.62 \%)$ was obtained in case of (sugarcane stem pieces + Grinded frond of date palm diet). Results obtained by Kaakeh et al., (2001) proved that nosignificant difference was observed in egg percent hatchability of RPW in cotton wools having honey solution and petri-dish lined with moistened filter paper as compared to other diets.

The success of the three tested natural diets in providing the necessary nutritional requirement for molting and development was based on data recorded in various life parameters of $R$. ferrugineus on these diets. The study on life parameters of $R$. ferrugineus included the following: fecundity or the number of eggs per female, egg viability or the percentage of hatch, larval developmental period, pupal period, percentage of larval survival, percentage of adult emergence, fecundity, fertility, and female : male ratio.

Previous attempts that were made by several researchers followed several steps: Sugarcane was a good substitute of coconut for rearing $R$. ferrugineus (Rahalkar et al., 1972); sugarcane was later incorporated in nutrient agar for feeding young larvae and sugarcane stem pieces for feeding of older larvae (Rananavare et al. 1975). Rahalkar et al. (1978, 1985) improved the culture of $R$. ferrugineus by developing an artificial diet containing sugarcane bagasse (fiber), coconut cake, yeast, sucrose, minerals, vitamins, and preservatives. 
Table 1. Effect of different diets on the durations of larval instars of R. ferrugineus under laboratory conditions.

\begin{tabular}{|c|c|c|c|c|c|c|c|c|c|c|c|c|c|}
\hline \multirow{2}{*}{\multicolumn{2}{|c|}{ Different diets }} & \multicolumn{12}{|c|}{ Mean duration of larval instars (days) } \\
\hline & & $1^{\mathrm{st}}$ & $2^{\text {nd }}$ & $3^{\text {rd }}$ & $4^{\text {th }}$ & $5^{\text {th }}$ & $6^{\text {th }}$ & $7^{\text {th }}$ & $8^{\text {th }}$ & $9^{\text {th }}$ & $10^{\text {th }}$ & $11^{\text {th }}$ & $12^{\text {th }}$ \\
\hline 1 & $\begin{array}{l}\text { Small pieces of } \\
\text { sugarcane stems }\end{array}$ & 1.79 & 2.79 & 2.10 & 3.13 & 3.08 & 3.93 & 6.92 & 8.01 & 11.47 & 15.04 & 15.11 & 16.1 \\
\hline 2 & $\begin{array}{l}\text { Sugarcane stem } \\
\text { pieces }+ \text { Sugarcane } \\
\text { residues }\end{array}$ & 2.09 & 2.99 & 2.31 & --- & --- & --- & --- & --- & --- & --- & --- & --- \\
\hline 3 & $\begin{array}{l}\text { Sugarcane stem } \\
\text { pieces + Date palm } \\
\text { trunk pieces }\end{array}$ & 1.99 & 2.16 & 2.51 & 3.83 & 3.37 & 3.05 & 6.02 & ---- & --- & --- & --- & --- \\
\hline 4 & $\begin{array}{l}\text { Sugarcane stem } \\
\text { pieces + Grinded } \\
\text { frond of date palm }\end{array}$ & 2.17 & 2.12 & 3.11 & 3.93 & 4.02 & 5.05 & 6.91 & 8.11 & 14.19 & 17.91 & 17.53 & 18.73 \\
\hline 5 & $\begin{array}{l}\text { Sugarcane stem } \\
\text { pieces + Food } \\
\text { residues of RPW }\end{array}$ & 1.27 & 2.02 & 1.65 & 2.63 & 2.95 & 3.13 & 4.06 & 5.71 & 10.12 & 12.97 & 13.69 & 14.43 \\
\hline
\end{tabular}

Table 2. Effect of different diets on some biological aspects of $R$. ferrugineus under laboratory conditions.

\begin{tabular}{|c|c|c|c|c|c|c|c|c|c|}
\hline & \multirow{3}{*}{ Different diets } & \multicolumn{7}{|c|}{ Development time (mean, days) } & \multirow{3}{*}{$\begin{array}{c}\text { Sex ratio } \\
\text { female } \\
\%\end{array}$} \\
\hline & & \multirow{2}{*}{$\begin{array}{c}\text { Mean } \\
\text { incubation } \\
\text { period of egg }\end{array}$} & \multirow{2}{*}{ Larva } & \multirow{2}{*}{ Pupa } & \multirow{2}{*}{ Total } & \multicolumn{3}{|c|}{ Longevity } & \\
\hline & & & & & & Male & Fen & rale & \\
\hline \multirow{2}{*}{1} & Small pieces of sugarcane & 4.02 & 89.47 & 21.00 & 98.81 & 88.97 & & & 55.87 \\
\hline & stems & $\pm 0.10^{\mathrm{a}}$ & $\pm 0.35^{\mathrm{b}}$ & $\pm 0.58^{\mathrm{c}}$ & $\pm 1.01^{\mathrm{b}}$ & $\pm 0.34^{\mathrm{c}}$ & \pm 0 . & & $\pm 0.27^{\mathrm{a}}$ \\
\hline \multirow{2}{*}{2} & Sugarcane stem pieces + & 4.54 & 103.78 & 34.00 & 114.45 & 92.44 & 87 & & 56.11 \\
\hline & Grinded frond of date palm & $\pm 0.05^{\mathrm{a}}$ & $\pm 1.08^{\mathrm{a}}$ & $\pm 0.29^{\mathrm{a}}$ & $\pm 0.79^{\mathrm{a}}$ & $\pm 0.80^{\mathrm{b}}$ & \pm 0 . & & $\pm 0.48^{\mathrm{a}}$ \\
\hline \multirow{2}{*}{5} & Sugarcane stem pieces + & 3.78 & 74.63 & 29.00 & 82.92 & 96.8 & 91 & & 56.72 \\
\hline & Food residues of RPW & $\pm 0.05^{\mathrm{a}}$ & $\pm 0.78^{\mathrm{c}}$ & $\pm 0.25^{\mathrm{b}}$ & $\pm 0.56^{\mathrm{c}}$ & $\pm 0.61^{\mathrm{a}}$ & \pm 0 . & & $\pm 0.53^{\mathrm{a}}$ \\
\hline \multicolumn{10}{|c|}{$\begin{array}{l}\mathrm{a}, \mathrm{b} \& \mathrm{c} \text { : There is nonsignificant difference }(\mathrm{P}>0.05) \text { between any two means, within the same column have the same } \\
\text { superscript letter. }\end{array}$} \\
\hline \multicolumn{10}{|c|}{$\begin{array}{l}\text { Table 3. Eggs deposited by } R \text {. ferrugineus females reared in their larval stage on different diets, kept with males } \\
\text { for } 63 \text { days, and exposed to multiple copulations. }\end{array}$} \\
\hline \multicolumn{2}{|r|}{ Diet } & \multicolumn{2}{|c|}{$\begin{array}{c}\text { No. } \\
\text { eggs/female }\end{array}$} & \multicolumn{2}{|c|}{$\begin{array}{c}\text { No. } \\
\text { eggs/female/day }\end{array}$} & \multicolumn{2}{|c|}{$\begin{array}{l}\text { No. Hatched } \\
\text { eggs }\end{array}$} & \multicolumn{2}{|c|}{$\%$ Hatching } \\
\hline 1 & Small pieces of sugarcane stems & \multicolumn{2}{|c|}{$198.76 \pm 0.52^{b}$} & \multicolumn{2}{|c|}{$2.70 \pm 0.10^{\mathrm{c}}$} & \multicolumn{2}{|c|}{$167.60 \pm 0.75^{b}$} & \multicolumn{2}{|c|}{$84.32 \pm 0.40^{\mathrm{a}}$} \\
\hline 4 & $\begin{array}{l}\text { Sugarcane stem pieces }+ \text { Grinded } \\
\text { frond of date palm }\end{array}$ & \multicolumn{2}{|c|}{$191.70 \pm 1.01^{\mathrm{c}}$} & \multicolumn{2}{|c|}{$1.65 \pm 0.04^{b}$} & \multicolumn{2}{|c|}{$160.30 \pm 0.91^{\mathrm{c}}$} & \multicolumn{2}{|c|}{$83.62 \pm 0.51^{\mathrm{a}}$} \\
\hline 5 & $\begin{array}{l}\text { Sugarcane stem pieces }+ \text { Food } \\
\text { residues of RPW }\end{array}$ & \multicolumn{2}{|c|}{$260.33 \pm 0.84^{\mathrm{a}}$} & \multicolumn{2}{|c|}{$3.40 \pm 0.05^{\mathrm{a}}$} & \multicolumn{2}{|c|}{$223.90 \pm 1.18^{\mathrm{a}}$} & \multicolumn{2}{|c|}{$86.01 \pm 0.40^{\mathrm{a}}$} \\
\hline
\end{tabular}

a, b \& c: There is nonsignificant difference $(\mathrm{P}>0.05)$ between any two means, within the same column have the same superscript letter.

All materials and diet (sugarcane, apple and cotton wools having $60 \%$ honey solution) showed significant difference among each other (Shahina $e t$ al., 2009). On the other hand, Jaya et al. (2000) recorded seven larval instars reared on sugarcane stem. Abe et al, 2009 indicated that, the head measurement of the larva during the development process. Alsuhaibani et al. (2001) categorized larvae into 3 young stages based on head capsule width $(<2.8 \mathrm{~mm})$, medium $(2.8-6.0 \mathrm{~mm})$ and mature $(>6.0$ $\mathrm{mm})$. Also Norzainih et al (2015), measured the head measurement of the larva during the development process.

\section{References}

Abe, F.; Hata, K. and Sone, K. (2009): Life history of the Red Palm Weevil, Rhynchophorus ferrugineus
(Coleoptera: Dryophthoridae), in Southern Japan. Florida Entomologist, vol 92: issue 3, 421-425. sept.. http://dx.doi.org/10.1653/024.092.0302.

Abraham, V.A.; Al-Shuaib, M. A.; Falleiro, J. R.; Abozuhairah, R. A. and Vidyasagar, P. S. P. V.(1998): An integrated approach for the management of red palm weevil Rhynchophorus ferrugineus Oliv. A key pest of date palm in the middle-East. Sultan Qaboos University Journal of Scientific Research (Agricultural Science), 3: 7783.

Alsuhaibani, A.M.; Aldafer, H.M. and Alahmadi, A.Z. (2001): Behavioral and biological studies on the red palm weevil, Rhynchophorus ferrugineus Oliv. (Coleoptera: Curculionidae) in Riyadh, Saudi Arabia. Research Bulletin No. (107), Agricultural 
Research Center, College of Agriculture, King Saud University, 5-30.

Barranco, P.; Pena, J.; Martin, M.M. and Cabello, T. (2000): Host range for Rhynchophorus ferrugineus (Olivier, 1970) and host diameter (Coleoptera: Curculionidae). Boletin de Sanidad Vegetal Plagas, 26(1): 73-78.

Buxton, P.A. (1918): Report on the failure of date crops in Mesopotamia in 1918. Agricultural Directorate, M.F.F. Bassarah, Ball. No. 6.

Dembilio, O.; Jacas, J.A. and Lacer, E. (2009): Are the palms Washingtonia filifera and Chamaerops humilis suitable hosts for the red palm weevil, Rhynchophorus ferrugineus (Col., Curculionidae). J. Appl. Entomol., 133: 565-567.

El-Garhy, M.E. (1996): Field evaluation of the aggregation pheromone of the red palm weevil, Rhynchophorus ferrugineus, in Egypt, Brighten Crop Protection Conference: Pest and Diseases, Proceeding International Conference, Brighton, UK, November 18-21, 1059-1064.

EPPO, (2008): European and Mediterranean Plant Protection Organization, Data sheets on quarantine pests, Rhynchophorus ferrugineus. EPPO Bull., 38: 55-59.

Faleiro, J.R. (2006): A review on the issues and management of red palm weevil $R$. ferrugineus (Coleoptera: Rhynchophoridae) in coconut and date palm during the last one hundred years. International Journal of Tropical Insect Science 26, 135-154.

Jaya, S.; Suresh, T.; Sobhitha-Rani, R.S. and Sreekumar, S. (2000): Evidence of seven larval instars in the red palm weevil, Rhynchophorus ferrugineus (Oliv.) reared on sugarcane. Journal of Entomological Research, 24: 27-31.

Jones, C. R. (1995): Insect notes from the Philippines. Philippine Agric. Rev., 6: 246-250.

Justin, C.G.L.; Leelamathi, M.; Thangaselvabai, T. and Johnson. S.B.N. (2008): Bioecology and management of the red palm weevil, Rhynchophorus ferrugineus Oliv. on coconut. a review, Agricultural Reviews 29: 117-124.

Kaakeh, W.; El-Ezaby, F.; Aboul-Nour, M. M. and Khamis, A. A. (2001): Mass rearing of the red palm weevil, Rhynchophorus ferrugineus Olivier, on sugarcane and artificial diets for laboratory studies: Illustration of methodology. Proceedings of the Second International Conference on Date Palm, AlAin, UAE, 344-357.

Kaakeh, W. (2005): Longevity, fecundity, and fertility of the red palm weevil, $R$. ferrugineus Olivier (Coleoptera: Curculionidae) on natural and artificial diets, Emirates Journal of Agricultural Science 17: 23-33.

Lal, M.M. (1917): Rept. Asst. Prof. Entomol: Rept. Dept, Sagr. Punjab, for the year ended $30^{\text {th }}$ June.

Lefroy, H.M. (1906): The more important insects injurious to Indian Agriculture, Govt. Press, Calcutta, India.

Lepesme, P. (1947): Les insectes des palmiers. Paris: P. Lechevalier. 904.
Liver, R.J.A.W. (1969): Pests of the coconut palm. FAO Rept., Rome,113-117.

Norzainih, J. J.; Harris M.N.; Nurul Wahida, O.; Salmah, Y. and Norefrina Shafinaz, M., N. (2015): Continuous Rearing of the Red Palm Weevils, Rhynchophorus ferrugineus (Olivier), 1970 on Sugarcane in Laboratory for Biological Studies (Coleoptera: Dryophthoridae). $3^{\text {rd }}$ International Conference on Chemical, Agricultural and Medical Sciences (CAMS-2015) Dec. 10-11, 2015 Singapore.

Rahalaker, G. W.; Harwalkar, M. R. and Rananavare, H. D. (1972): Development of red palm weevil, Rhynchophorus ferrugineus Oliv. Indian J. Entomol. 34: 213-215.

Rahalaker, G. W.; Tamhankar A. J. and Shanthram, K. (1978): An artificial diet for rearing red palm weevil, Rhynchophorus ferrugineus Oliv. J. Plantation Crops 6: 61-64.

Rahalaker, G. W.; Harwalkar, M. R.; Rananavare, H. D.; Tamhankar, A. J. and Shanthram, K. (1985): Rhynchophorus ferrugineus, P. Singh and R. F. Moor [eds.]. Handbook of insect rearing. Elsevier, New York, NY. 1: 279-286

Rananavare, A. J.; Shanthram, K.; Harwalkar, M. R. and Rahalkar. G. W. (1975): Method for the laboratory rearing of red palm weevil, Rhynchophorus ferrugineus Oliv. J. Plantation Crops 3: 65-67.

Salama, H.S. and Abdul Razek, A.S. (2002): Development of red palm weevil Rhynchophorus ferrugineus (Oliv.) (Curculionidae: Coleoptera) on natural and synthetic diets. Anzeiger fur Scha dlingskunde, 75: 37-139.

Saleh, M.R.A. (1992): Red palm Weevil, Rhynchophorus ferrugineus (Oliv.). The first record for Egypt and indeed the African Continent, List No. 10634 Africa, Collection No. 22563. British Museum Report of International Institute of Entomology, 56 Queen's Gate, London, SW 75 JR UK: p. 1.

Saleh, M.R.A. and Gouhar, K.A. (1993): Red palm weevil attacking date palm trees in limited areas of Egypt at the present time and how can be eradicated from these areas. Report of Plant Protection Department, Fac. of Agric. Zagazig Univ., pp. 20.

Shahina, F.; Salma, J.; Mehreen, G.; Bhatti, M.I.; and Tabassum, K.T. (2009): Rearing of Rhynchophorus ferrugineus (Oliv.) in laboratory and field conditions for carrying out various efficacy studies using EPNs, Pak. J. Nematol, 27(2): 221-231.

Steel, R.; Torrie, J. and Dickey, D. (1997): Principles and procedures of Statistics: A Biometrical Approach, $3^{\text {rd }}$ ed., McGraw-Hill, New York, NY.666 pages.

Wattanapongsiri, A. (1966): A revision of the genera Rhynchophorus and Dynamism (Coleoptera: Curculionidae), Department of Agricultral Science Bulletin, Bangkok, Thailand, 1966, 328. 